\title{
The Role of Social Networks in Trade Union Recruitment: The Case Study of a Radical Union in Spain
}

\author{
Beltrán Roca, Universidad de Cádiz, Spain
}

\begin{abstract}
In a general context of union decline, radical trade unions are experiencing a moderate growth in contemporary Spain. This article examines the channels through which workers join radical unions. It applies social network analysis to the study of recruitment in 2012 by the local branch of the Confederación Nacional del Trabajo (CNT) in El Puerto de Santa María, Spain. It concludes that pre-existing social networks (co-workers, family and friends) are essential in trade union recruitment. Due to the rapid growth of the local branch and to the characteristics of this union, the findings of this case study can shed light on the general debate on union membership.
\end{abstract}

\section{KEY WORDS}

trade unions, radical trade unionism, social network analysis, union recruitment, social capital unionism, trade union renewal, Spain, anarcho-syndicalism

\section{Introduction: Spanish Union Membership between Crisis and Renewal}

The Spanish labour movement is currently in a stage of crisis. The context of economic retrenchment, which is seriously affecting Southern Europe, and the neo-liberal hegemony expressed in Spain by the victory of the conservative Partido Popular in the general elections of 2011, but also in the agenda of the Socialist Party — has threatened trade union power (Köhler and Calleja Jiménez, 2013: 15). The response of the two main union confederations, Comisiones Obreras (CCOO) and Unión General de Trabajadores (UGT), is directed mainly at a return to a stage of great social agreements.

In this context, only a small part of the Spanish workers' movement, more connected to civil society organisations, advocates rebuilding the bases of the labour relations system and increasing the level of struggle in the streets and workplaces in order to stop, and reverse, current social policies. Following Offe (1992), some unions, in the light of a loss of institutional support in a period of crisis, aim to move towards union renewal and counter-power. Some of these are radical unions such as the Confederación General del Trabajo (CGT), the Confederación Nacional del Trabajo (CNT) and the Sindicato Andaluz de Trabajadores (SAT). ${ }^{1}$ It is noteworthy that while CCOO and UGT have lost members due to deregulation (Jódar et al., 2012: 140), radical unions are experiencing a considerable growth in members and mobilisation power.

\footnotetext{
${ }^{1}$ For a deeper understanding of current radical unions in Spain, see Florido, Roca and Molina (2013).
} 
Radical trade unionism can be defined as the social space constructed by those labour organisations which: a) are influenced by revolutionary ideologies and left political organisations; b) develop their action separately from social partnership, advocating for conflict and, to a lesser extent, negotiation; and c) have defined their identity in opposition to hegemonic trade unions, which they critique for their lack of internal democracy, their external dependence and their low level of confrontation against political and economic powers. Another characteristic of Spanish radical trade unionism is its opposition to the social pacts which took place during the political Transition in the 1970s. Although this type of organisation has tended to be ignored in academic research on Spanish labour relations and political history, they are attracting attention due to the current delegitimisation of the dominant trade unions, CCOO and UGT, as well as for their affinity with emergent social movements such as the M15 (Roca and Díaz, 2013: 856). As Connolly and Darlington (2012: 236) have stated, radical political trade unionism can make significant contributions to union revitalisation, delivering bargaining gains and fostering political opposition to government and neo-liberalism.

This article aims to analyse the recruitment channels of radical trade unions in Spain. To do so, it will study the affiliations to the CNT local branch in El Puerto de Santa María (Cádiz, Spain) during 2012. First, it presents and justifies the selection of the case study. Second, it analyses the existing literature on union recruitment, social capital and union revitalisation in order to identify the variables for the study. Third, it explains how the author has used social network analysis for exploring union membership and strategy. Finally, the article includes the main findings from the social network analysis of the studied case.

\section{Presentation of the Case: A Radical Union in an Andalusian Post-industrial City}

El Puerto de Santa María is a post-industrial city located in the Bay of Cádiz in southern Spain, which had 88917 inhabitants in 2013. One cannot understand the local economy without relating the city to the other cities of the Bay, with which it is closely connected. In general terms, it is a residential area for white-collar workers and professionals from the service sector and, to a lesser extent, for industrial workers who work in other cities of the area. One of the main features of its labour market is its high unemployment rate. In 2011 there were 11963 persons registered with the Public Employment Office. In addition, El Puerto is a tourist destination. One of the engines of the local economy is "sun and beach" tourism. All this is reflected in the weight of the economic sectors. In 2008, for example, the main activity was the service sector (88 per cent). The other sectors had a secondary place: building ( 7 per cent) and industry (5 per cent). With the development of the economic crisis, the relative weight of the industrial and building sectors have diminished even more in recent years. In relation to service activities, the most important was the commercial sector, followed by property development and company services, ${ }^{2}$ and the hospitality sector (Ayuntamiento de El Puerto de Santa María, 2008).

Regarding the size of the companies, 88.6 per cent have less than five employees. There are only 200 businesses with more than twenty employees. Small and medium sized companies prevail. The biggest companies established in the city belong mainly to public services and the iron and steel

\footnotetext{
${ }^{2}$ It is not possible to separate the data of the property development industry from company services in the documents of the Statistics Department of the City Council. In any case, since 2008 the weight of the property development sector has experienced a radical decline.
}

Global Labour Journal, 2016, 7(1), Page 21 
industry. As will be seen below, this had an effect on the launching of the local union.

CNT was launched in El Puerto de Santa María in 1996. ${ }^{3}$ Shortly afterwards, union organisers occupied an abandoned building which had belonged to workers organisations (UGT and CNT) before the Civil War. ${ }^{4}$ The initial core of the local branch was led by a worker from the shipyard of Puerto Real, a neighbouring city, ${ }^{5}$ and a group of students. During the following twelve years, the organisation did not manage to recruit more than twenty members, and carried out activities more related to anarcho-syndicalist propaganda than what could properly be called unionism.

In 2008, however, the local branch began a renewal process, along the lines followed by other branches all over the country. ${ }^{6}$ This renewal process drew on three axes: a) the launching of a service that provided free legal labour advice for all workers, for which they hired the services of an external lawyer; b) the updating of the union's image, using new information technologies such as Facebook and their own website; and c) intensive membership union training. Thereby, they acted as consultant to a growing number of workers, filing lawsuits, recruiting members and taking part in collective labour struggles.

The singularity of CNT is that it is a union which does not participate in elections for works councils. $^{7}$ It focuses its activity on worker assemblies and the union section. Contrary to works councils which represent the whole staff, these union sections only represent unionised workers inside the company, and have fewer competences according to the legal framework (Workers' Statute and Organic Law 11/1985 of Trade Union Freedom). Consequently, the CNT can hardly introduce itself in big companies and compete with other unions which control works councils and virtually monopolise collective bargaining.

Since 2008 the local branch has continued to grow. From 2008 to 2013 it experienced an increase of 1750 per cent. In 2012, according to the union database, they acted as consultant in a total of 105 cases, both individual and collective. Moreover, it managed to set up union sections in several of the most important companies of the area, such as the public home help service, street cleaning and electricity subcontracts. During the last year of crisis, with massive unemployment which has negatively affected recruitment in the major unions and with an unfavourable framework for the CNT union model, the union has grown consistently. This rapid growth is why the analysed case can contribute to identifying the factors affecting recruitment in radical unions.

The case study has been selected for two reasons. First, El Puerto de Santa María is a post-

\footnotetext{
3 Previously, since 1910, and especially in the 1930s, there was a local branch of CNT in the city with hundreds of members. A few days after the fascist coup d'état of 1936 the city fell into Francoist hands and labour societies were declared unlawful. See Gutiérrez Molina (1993) for an insightful approach to the anarcho-syndicalist movement in the province of Cádiz.

4 After the victory of the Socialist Party in 1982, Law 4/1986 was proclaimed, according to which the government would give back premises, furniture, funds and historical and cultural documents requisitioned from labour organisations after the coup d'état of 1936.

${ }^{5}$ During the 1980s and 1990s CNT played a key role in the struggles against industrial restructuring in the shipyard of Puerto Real (Pérez de Guzmán, 2012).

6 The agreements of the 10th Confederal Congress, celebrated in Córdoba in December 2010, were the result of such institutional shift (CNT, 2012).

7 For further information and viewpoints about the evolution of CNT since the Spanish transition to democracy, see Gómez Casas (1984) and Ibáñez (2007).
} 
industrial, medium-size city; like most of the Spanish economy the services sector is the main focus of activity. Secondly, the CNT local union has experienced an important membership growth since 2008 due to a process of internal renewal. CNT can be considered a paradigmatic example of a radical union and is currently experiencing significant growth. Although the article explores a case of a relatively small radical trade union in a country under a particular system of labour relations, the comparison of the findings with successful revitalisation processes in other countries can provide an insightful view into the factors which contribute to the promotion of radical unionism in other contexts. In addition, it can help to identify successful tactics which could be tested in other countries and organisations.

\section{Union Recruitment, Collective Action and Social Capital}

Recruitment is one of the areas most studied by trade union researchers (Waddington and Whitston, 1997; Schnabel, 2003; Beneyto, 2004; Björkman and Huzzard, 2005). In Spain it is not easy to know with precision how many workers are in each trade union. The most trustworthy data comes from the Work Life Quality Survey (ECVT in Spanish), run by the Ministry of Work. According to these inquiries, the rate of union membership in Spain has experienced ups and downs, but it is - at best - slightly under 20 per cent of employees. However, recent research has demonstrated that massive unemployment, a consequence of economic crisis, has reversed the growing tendency in union recruitment in Catalonia (Jódar at al., 2012). This conclusion can probably be extended to all the regions of the country.

The profile of unionised workers is not homogeneous. According to the 2006 Work Life Quality Survey, the profile of unionised worker is: male, public-sector employee, with a monthly salary higher than $€ 1200$, with an indefinite and full-time contract, in a company with more than 250 employees, or a blue-collar worker, technician or professional, and aged between 45 and 65. The results of this report make clear that there are significant sectors of workers that trade unions do not manage to recruit or represent. This is due to multiple reasons, but an essential one is that most workers are employed by small companies in which it is extremely difficult to carry out union activities, and, in addition, where it is not possible to hold union elections. Spanish majority unions tend to represent workers from big companies, because that is where they are able to achieve elected delegates. Depending on the number of elected delegates in a territory, they receive institutional power and public funding. Consequently, mainstream union strategies in Spain are focused only towards a reduced part of the workers.

Workers join unions driven by two motivations which relate to a double logic: the utilitarian/rational and the identification/expressive. In this sense, the analysis on union recruitment is closely linked to the theoretical approaches to collective action (Letamendia, 2013: 11). On the one hand, workers join unions with an instrumental orientation, because being a member brings several benefits (such as legal advice, collective bargaining or services). This coincides in essence with a resources mobilising theory of collective action, according to which social protest is in a certain way the result of an individual and collective calculation in which actors and organisations balance political opportunities and available resources (Tarrow, 1998; McAdam, Tarrow and Tilly, 2005). But on the other hand, union membership - like social mobilisation - is also motivated by ideologies, work cultures, feelings, identities and loyalties (Florido, Roca and Molina, 2013: 895). Every union 
member or collective action participant combines both motivations, although in different proportions.

Within the identification/expressive motivation one dimension stands out which is very often overlooked in research on union recruitment: the logic of interaction (Letamendia, 2013: 13). In accordance to this logic, workers' need of social integration and sociability is a key factor in union recruitment. The union can fulfil the human desire for belonging to a group. From this point of view, social networks and the articulation between union and community are key issues in union recruitment and action (Urano and Stewart, 2009). Therefore, trade unionism is closely related to social capital.

Trade unions build social networks which can be mobilised under certain circumstances (such as getting support for strike action, for an advocacy campaign or for a union election). Nevertheless, there are many definitions of social capital. Bourdieu (1991), for instance, defines it as the aggregate of the resources of a social agent which derives from his or her possession of a durable network of mutual acquaintance and recognition. This type of capital is essential in order to understand the agents' strategies for reproducing the social structure. Other scholars, on the other hand, emphasise the collective dimension of social capital. Putnam (1999), for example, affirms that dense cooperation networks are a requisite for democracy and social development. From this point of view, reciprocity between individuals can enhance civic participation, trust in government and welfare.

Trade unionism is, by definition, the organisational result of solidarity ties among workers, who self-organise to help each other and defend their collective interests against political and economic powers. In this sense, trade unions are, without any doubt, one of several civil society organisations which can contribute to the extension of social capital. Several authors have analysed union membership and behaviour through these lenses. Ebbinghaus, Göbel and Koos (2011: 110), for example, point out that social capital is one explanation for the differences in union density among countries. Hurd, Milkman and Turner (2003) explain that coalition building is one of the main strategies for union revitalisation. Other authors argue that international cooperation among trade unions and social movements can increase their effectiveness both in influencing social policies (Turnbull, 2010: 346) and in collective bargaining (Gollbach and Schulten, 2000; Glassner and Pusch, 2013). Urano and Stewart (2009) suggest that providing legal consultancy, incorporating community demands in the union agenda, focusing on marginal workers and joining a big federation can be essential elements for a successful strategy.

In addition, other researchers focused on unions' internal relationships - that is, on the role of networking among union members and sympathisers. From this viewpoint, unions can be considered communities (Johnson and Jarley, 2005: 608) and their strategies for scaling up their associative power can be thought of as the building and strengthening of social capital. In past industrial societies, workplaces and communities were strongly connected. In such a context, social reciprocity norms favoured union membership and participation. Today, post-industrial societies have weakened - if not destroyed - those links between workplace and community. That is why organising strategies tend to activate social solidarity. As Johnson and Jarley (2005: 609) have stated, "Contemporary efforts to revitalise unions through implementation of the 'organizing model' can be viewed as an effort to improve union member network density by reducing hierarchy and vesting more power in activist members". 


\section{Methodology: Using Socio-metric Analysis for the Study of Union Recruitment}

Visualising is common practice in many scientific disciplines. Photographs, films and sociograms are being increasingly used in the social sciences, both in the analysis of social reality and in disseminating research results. In particular, social network visualising can be of great interest to social researchers for understanding the structure of such networks and presenting the outcomes of their analysis (Freeman, 2000).

Social network analysis studies the specific relations among a given set of elements, such as persons, groups, organisations or even events (Molina, 2001: 2). From this perspective, actors' behaviour is assumed to be a result of their participation in structured social relations. The main difference between conventional and reticular data is that while conventional data is focused on actors and their attributes (such as class, gender or education), network data is focused on the actors and their relationships. This does not mean that attributes are not taken into account. In fact, attributes and reticular data can be combined in social network analysis. There are two different kinds of social network analysis. Some researchers use "network" as a metaphoric concept for the qualitative study of social relations, while others use it as a formal method for the study of social structure (Molina, 2001). In both cases, the set of relationships among the analysed elements (nodes) can be used to design and visualise networks, but only in the second type of analysis is it possible to use computer software and socio-metric operations.

From the pioneer socio-metric analysis of Jacob Moreno (1934) and the theories of structural equilibrium of Cartwright and Haray (1956), social network analysis has been consolidated as a recognised research technique used in several fields, such as migration, policy making, public health, communications and mass media, social capital and organisational dynamics (Molina, 2001: 37-57). One of the emerging areas of study of social networks is social movements and collective action. This perspective emphasises the role of interpersonal networks in cultural and political transformations. It can be used as a complementary approach with other theoretical frameworks in order to understand collective action (Diani, 1998). Although social networking has been widely studied in contemporary social movements (Della Porta, 1998; Juris, 2009), its role in the labour movement needs more analysis.

This article will apply the Social Network Perspective ${ }^{8}$ to the analysis of union recruitment in a local branch of a Spanish radical union. The data has been collected by means of documental observation and participant observation; the researcher had a double role as anthropologist and as union organiser.' As a union organiser during 2012, the researcher had access to the membership database of the local branch.

\footnotetext{
${ }^{8}$ For a general introduction to social network analysis, see Molina (2001).

9 The main implication of having a double role as researcher and practitioner is the type of questions I formulate about social reality. Following the principles of "action research", I have selected research questions which can contribute directly to improving social practices and strategies for the organisations involved. Thus, pure academic goals are put in second place.
}

Global Labour Journal, 2016, 7(1), Page 25 


\section{Findings: Union Recruitment and Social Networks}

According to the database of the Organisation Secretary of CNT's local branch in El Puerto de Santa María, it recruited 79 new members in 2012. This database contains valuable information for classifying such members. Of those persons, 65 were male $(82.3$ per cent) and 14 were female (17.7 per cent). The majority of the recruits were in the iron and steel industry ( 65.8 per cent). All of them were male; 12.6 per cent of the recruits came from the cleaning services industry, nearly all of them women. To a lesser extent, the new members came from industries such as retail, education, hospitality, construction and others (wood, health care, retired, and public services).

By interviewing the representatives of the local committee ${ }^{10}$ it was possible to get information about recruitment channels. In particular, two questions were asked which were regarded as relevant: First, who joined the union to solve his/her problems at work and who joined due to his/her identification with the organisation and its ideology? Second, which person(s) acted as a link between the union and each new member?

The answers to the first question clarified people's motivation for joining the union in such a period. It was observed that only 12.6 per cent of the new recruits were motivated by identification with the union, its political goals and its ideology. In fact, 87.4 per cent of the recruits were motivated by an instrumental interest. The new members were in most cases workers who attended for legal and organisational support in order to defend their immediate labour interests. As the CNT database reflects, such labour problems were mainly firings, work stoppages, sanctions, modifications of labour conditions and defaults of contracts.

The second question allows us to understand the union's recruitment channels. In particular, it made it possible to make a sociogram to analyse the connections among veteran members, supporters and new members. In order to visualise the sociogram and analyse the network features, the computer software Ucinet 6 was used (Borgatti, Everett and Freeman, 2002). Thereby, it was verified that most of the recruits-92.4 per cent-got in contact with the union through another person (mainly someone who was already a member). Only 7.6 per cent of the recruits knew about the union through propaganda, local press or the Internet. Hence, It can be concluded that the growth of this kind of union is based mainly on pre-existing social networks. Nevertheless, it was shown that among those people who knew about CNT through mass media and propaganda, those moved by ideological and expressive incentives prevailed. Besides, this group of people maintained a more frequent active participation in union meetings and activities. By contrast, utilitarian motivations prevailed among people who arrived by means of pre-existing social networks, and there was much less frequent active participation in the organisational life of the union.

In order to deepen the social network analysis it was asked which specific persons had acted as a bridge between each new member and the union. Moreover, the type of relation each new member had with his/her "bridge person" (co-worker, relative or friend) was explored. Thus, depending on the type of bond, of the 73 recruits who joined in 2012 via social networks, 60 were made by coworkers, 8 by friends and 5 by relatives. It can be concluded that union action within companies is the main source of recruits, although the role of family relations and friendship is also significant in bringing workers to the organisation.

10 The local committee currently consists of four persons who perform the functions of General Secretary, Union Action Secretary, Organisation Secretary and Treasurer.

Global Labour Journal, 2016, 7(1), Page 26 
A matrix was made from the responses about the persons who influenced the recruitment of new members, which made it possible to visualise the network using the computer software. As can be seen in Figure 1, the network consisted of 92 nodes -73 new members who got in touch with the union in 2012 by means of other people (in gray); 17 veteran members, who had mediated in the recruitment process in 2012 (in black); and 2 members of local community organisation, who also mediated in the recruiting episodes (in white). ${ }^{11}$

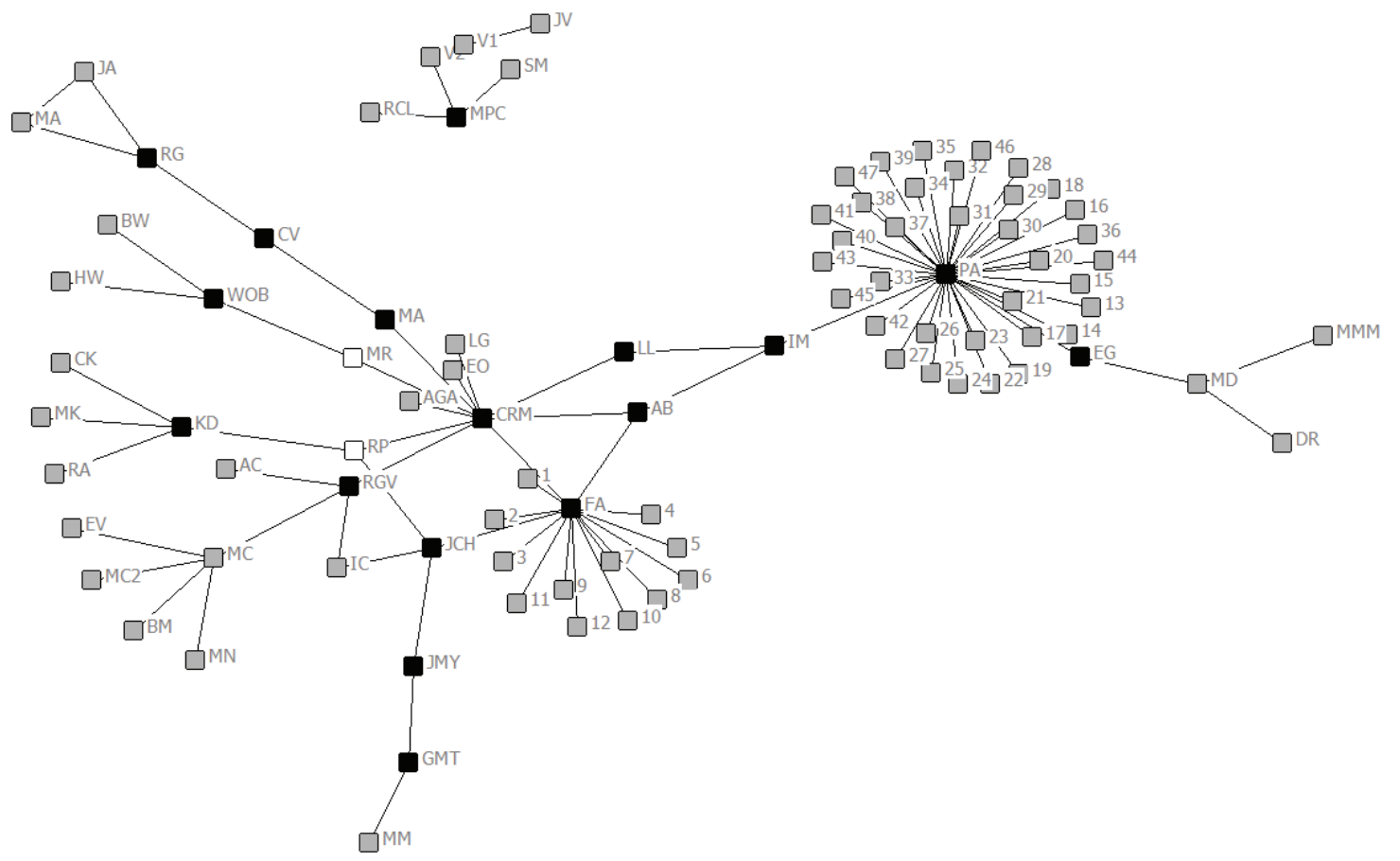

Figure 1. Sociogram of the recruitment channels in 2012

Given that most of the new members were recruited by co-workers, the union sections in which the recruitment had been made were represented in a new graph with colours (Figure 2) - union section A, automobile firm (blue); union section B, electrical assemblies firm (black); union section C, cleaning services firm (gray); union section D, industrial refrigeration firm (pink); union section E, home help service firm (dark green); and union section F, urban cleaning firm (clear green). The nodes represented in red did not belong to any union section. Figure 2 highlights the importance of union section creation for trade union growth. Workplaces are the most important space for union recruitment. Co-workers are the main recruiters. As the local branch representatives explained, the

${ }^{11}$ These community organisations are the Pro Human Rights Association of Andalusia, which has a room in the local CNT branch premises, and the Portuense Social Forum, a local network of grassroots organisations to which CNT is affiliated. 
drive for these workers to join the union used to be conflicts at work (collective terminations, contract defaults, delocalisations or modifications to working conditions). Union recruitment was, therefore, something more reactive than proactive.

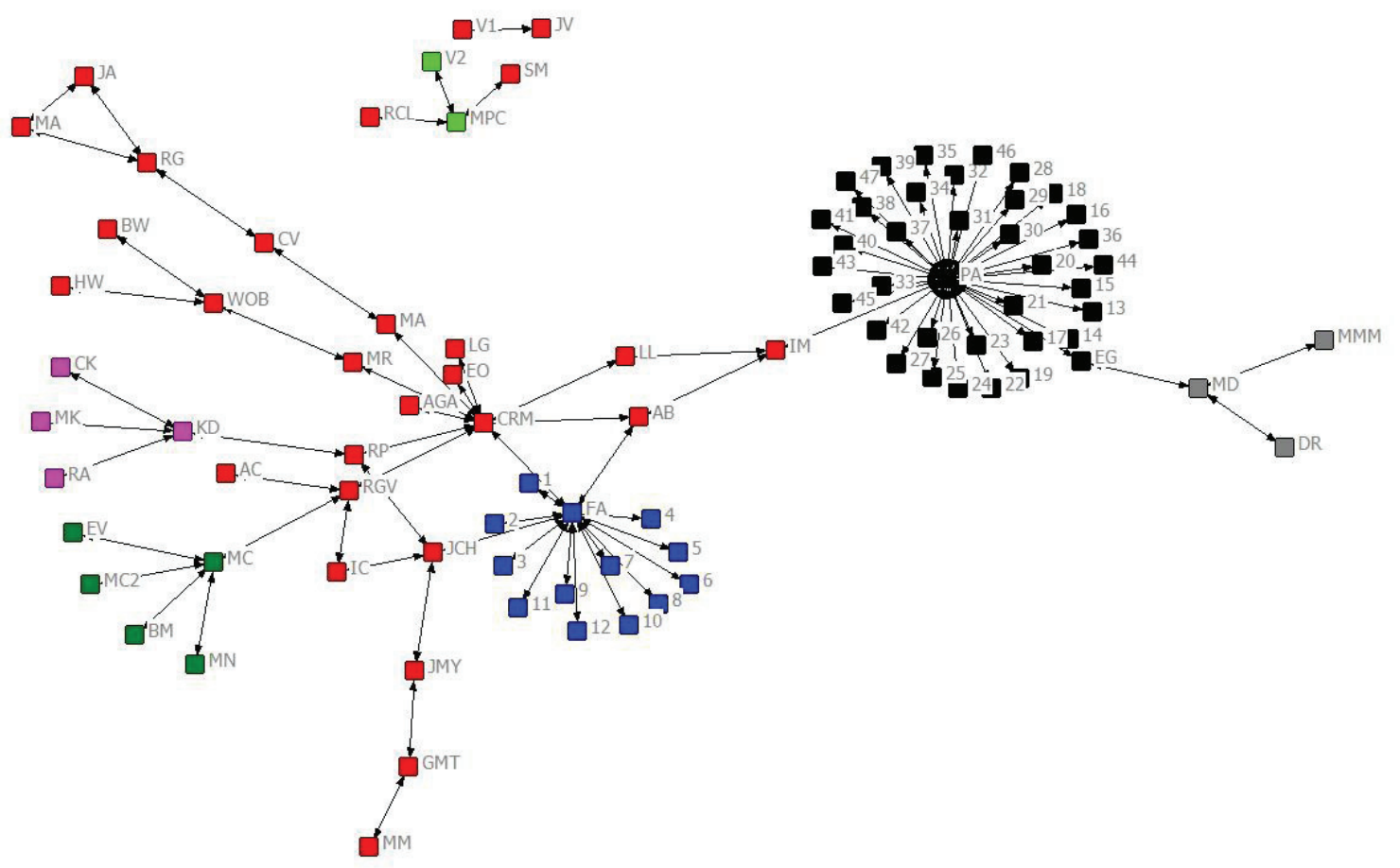

Figure 2. Recruitment network differentiating union sections, 2012

In order to visualise family networks a sociogram was designed in which actors connected by family links were coloured in red (Figure 3). This graph allowed identification of those union organisers who recruited more workers from among their relatives. In particular, MPC, EG, RG and JCH stood out for bringing relatives to the union.

Designing a binary relational matrix allows for a socio-metric analysis which could help to identify relevant characteristics of the informal organisational structure. In particular, it is possible to examine subgroups (cliques) within the union and to study the centrality of certain members. There are two types of cliques: strict-sense cliques and wide-sense cliques. The first type consists of a subgroup whose members share all the possible links among them. It would be a strongly connected group. It is probable that strong cliques have since developed in the relational network of the union, but the sociogram created for this research - asking only about the links involved in recruitment does not allow their recognition. An f-groups analysis - identifying subgroups composed of triadic relations (Borgatti et al., 2002) - confirms that there are no strong ties. 


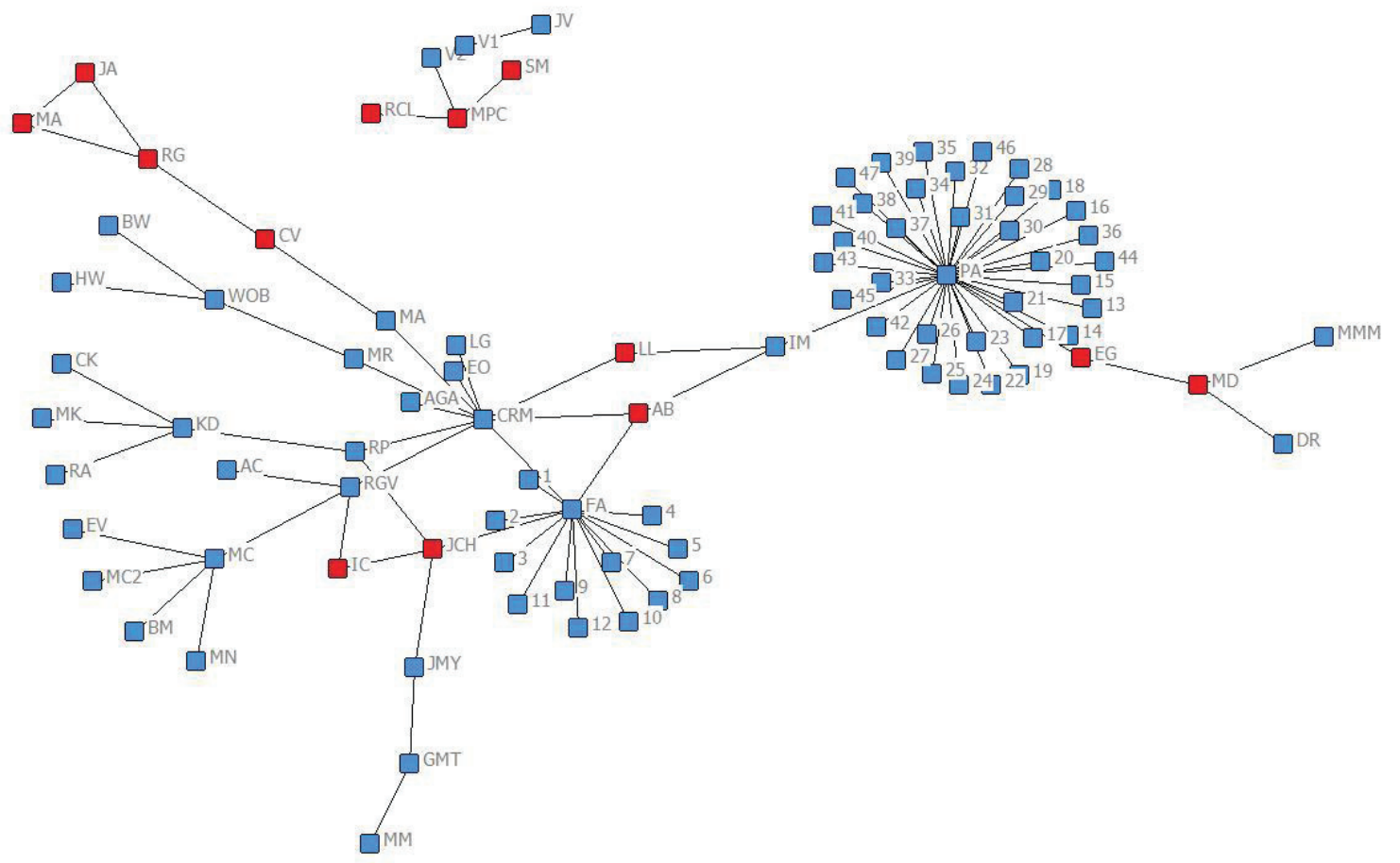

Figure 3. Recruitment network emphasising family links, 2012

Nevertheless, other socio-metric operations allow for the identification of subgroups with a lesser degree of internal interconnections which can be sociologically relevant. This is the case, for instance, of the N-clan application, which recognizes both direct and mediated relations among the nodes (one has access to someone because he/she shares a common contact), but all the links must be reached by means of other members of the clique. Using the N-clan tool, 21 groups of more than 3 actors become apparent within the network. Most of these subgroups coincide with union sections and members connected by pre-existing family and friendship relations.

An examination of centrality measures can provide useful data. Three measures of the network have been analysed: degree, betweenness and closeness. The degree is the number of direct connections of a member - that is, the number of nodes to which one node is linked. In this case, a higher degree means that this person has directly recruited a higher number of members. This identifies the most active recruiters of the union. It can be seen in Figure 3 that the main recruiters are PA and FA, both delegates of big union sections in iron and steel firms, and CRM, secretary of union action. Other recruiters are delegates of smaller union sections - or union sections which have grown very little in 2012, activists and representatives of the local committee.

Having good recruiters is as important as enrolling new recruiters. Betweenness reflects the frequency with which an actor appears in the shortest plot (or geodesic) which connects two other nodes. In other words, it reveals when a member acts as intermediary between two members. This type of "bridge person" has a huge potential for connecting subgroups or cliques. According to the centrality analysis, the main bridge persons of the analysed network are PA, IM, AB and FA. Finally, 
centrality closeness points out the capacity of a member to reach out to the rest of the members of the network. For calculating centrality closeness of a given node, not only is the number of direct links of such a node important but also the centrality (the number of links) of those nodes to which it is connected. The initials of the actors who have a higher closeness centrality are AB, IM, PA, CRM, LL and FA. These members - again local representatives, union delegates and activists play a key role in organisational internal communications. They must be borne in mind in order to develop strategies for mobilising the membership.

\section{Discussing the Case}

The data collected in this case study can shed light on broad debates on the possibilities of radical unionism for union renewal (Connolly, Kretsos and Phelan, 2014: 2). First, it confirms previous findings on the successful strategy of providing legal services to attract membership in radical unions (Denis and Damesin, 2005: 17). The analysed local branch started to grow after contracting the services of a labour lawyer.

Secondly, this study has demonstrated that social network analysis enables the discovery of previously unexplored dimensions of trade union recruitment. This research perspective has proven especially apt for inquiring into membership recruiting channels. In the studied local branch, 92.4 per cent of the recruitments in 2012 were mediated by other people. Union growth, therefore, follows a "snowball" model, in which members and sympathisers act as bridges between the organisation and new members. Achieving a counter-power strategy, in which participation and political engagement are again at the centre of union activity, could be possible by making use of pre-existing social ties (and it can be extended to both radical and mainstream trade unions).

Despite these facts, collected data demonstrates that the workers who joined the union through word of mouth were usually driven by instrumental motivations and scarcely got involved actively in the internal life of the union. The small 7.6 per cent of the recruits who knew about the union by means of propaganda, political publications and the Internet had more ideological and expressive motivations and were clearly more involved in organisation activities. As a result, recruitment by means of social networks should be strengthened simultaneously with an equal effort to improve ideological union propaganda and communication.

Another significant question is the profile of the union members. It is a remarkable fact that in a post-industrial municipality, in which 88 per cent of the economic activity comes from the service sector and more than the 90 per cent of the firms are small sized, the membership profile of a radical union does not differ from major ones in general terms (see, for example, Beneyto, 2004: 21). The research has shown that most of the recruits are male and come from union sections in iron and steel industry firms with more than 50 employees. In this sense, CNT's claim about the efficiency of its model in small and middle size firms cannot be verified. It raises serious doubts about the capacity of radical unionism to recruit and mobilise non-unionised workers effectively.

In order to analyse the recruitment network, a sociogram consisting of 92 nodes has been elaborated. There were 73 nodes representing the new recruits in 2012 who came to the union by means of their social networks (co-workers, family or friends). The other nodes represented union members and supporters from community organisations who mediated in the recruitment of the 73 new members. Visualising the sociogram allows us to recognise the key role of union sections within 
the companies in recruiting members. It can thus be stated that work centres are still the main locus of radical union action. In addition, it can be observed that a good proportion of the new members came to the union through relatives.

There are only two actors in the graph who belong to community organisations (RP and MR). However, despite having only two nodes, they do not have a minor role. Both actors were bridges between the local branch and people who recruited several members. The sociogram only reflects the recruitments in 2012, but RP recruited KG to the union, who recruited 12 co-workers in 2011. MR also recruited WOB, who recruited 7 other co-workers (construction workers from Mauritania and Algeria, who had specific labour and social problems) before 2012. Strengthening links with community organisations has revealed a good strategy for union introduction in firms and territory. This points to the value of doing some sort of community unionism (Urano and Stewart, 2009: 121). The studied union is already part of a local network of community organisations, the Portuense Social Forum, although its everyday activities sharply separate social action with the community from union action inside the firms.

Analysis of centrality measures of the sociogram can also provide useful information, even if its conclusions are only partial because the constructed network does not include all the union members (only those recruited in 2012 and their recruiters). The matrix degree allows the identification of the actors who recruited more new members. Those are delegates of union sections (mainly from the iron and steel sector) and representatives of the Local Committee. Betweenness centrality reflects those persons who may have not themselves have recruited many members, but who had connected sub-groups (cliques) within the network. The bridging role of these actors is essential for both recruitment and internal communications. Another centrality measure which helps to distinguish relevant actors for internal information flows is closeness. This measure not only reflects the direct links of a node, but also considers the centrality of other nodes to which these nodes are connected. As occurs with the other centrality measures, these actors are local representatives, union delegates and active militants.

An important problem not addressed by this research is the duration of union membership. Throughout the studied year, a high proportion of the new members left the organisation. This is related to several factors: the instrumental attitude of those who join the union (most of the recruits came to the union looking for legal advice, and some of them left as soon as their labour problem was solved); the problems which several union sections have had to face (some campaigns have ended up in collective terminations and delocalisations, and after that, unemployed, the workers left due to their economic difficulties); and the anti-union policies of certain bosses which have fostered union decline. This problem suggests the limitations of radical industrial action suggested by Denis (2012: 271): radical collective action cannot be sustained over time. When the problems have been solved, workers might tend to prefer more moderate trade unions.

\section{Conclusions}

This article has addressed the problem of recruitment in radical unions. It has analysed the channels and dynamics of union recruitment of the CNT local branch in El Puerto de Santa María, Spain. The main conclusions are that the recruitment of members follows a snowball model — that is, it operates mostly by means of pre-existing social networks - and that shop-floor union action and 
legal advice are key factors. The analysis of the recruitment network shows that some individuals play an active role in recruiting new members in certain spaces, mainly within their companies, friends, family and community organisations. The article has also identified important obstacles to the development of radical unionism: the pre-eminence of instrumental motivations, the short duration of part of the membership and anti-union employer practices.

Finally, it can be stated that, even for radical unions, achieving union renewal and counterpower — using Offe's (1992) terminology — would require new strategies for promoting members' participation (Nicholson, Ursell and Blyton, 1981; Byford, 2009) and recruiting more activists driven by expressive and political motivations (Letamendia 2013: 13). As Fernández Rodríguez, Ibáñez Rojo and Martínez Lucio (2014: 111) have argued, it is very early to recognise the implications of the Spanish M15 movement. In the electoral arena it has recently crystallised in the emergence of the new Podemos party. In the trade union arena, major Spanish unions are in an ambiguous position between the status quo and social protest (Köhler and Calleja Jiménez, 2013: 15), and radical unions have only experienced a moderate growth. Being aware of the relevance of social networks, as this case study has pointed out, is vital in order to develop successful recruitment tactics to face the challenges imposed by globalisation and economic crisis.

\section{REFERENCES}

Ayuntamiento de El Puerto de Santa María (2008) Diagnóstico sobre el sector industrial de El Puerto de Santa María. El Puerto de Santa María: Ayto.

Beneyto, P.J. (2004) La afiliación sindical en España: Viejos tópicos y nuevas realidades. In Afiliación sindical en Europa: Modelos y estrategias, Volume 1, edited by P.J. Beneyto. Valencia: Ediciones Germanía.

Björkman, H. and T. Huzzard (2005) Membership Interface Unionism: A Swedish White-collar Union in Transition. Economic and Industrial Democracy, 26(1): 65-88.

Bourdieu, P. (1991) El sentido práctico. Madrid: Taurus.

Borgatti, S.P., M.G. Everett and L.C. Freeman (2002) Ucinet for Windows: Software for Social Network Analysis. Harvard, MS: Analytic Technologies.

Byford, I. (2009) Union Revitalisation and the Canadian Auto Workers Union: Reconnecting Union with Local Communities. In Community Unionism: A Comparative Analysis of Concepts and Contexts, edited by J. McBride and I. Greenwood. Basingstoke: Palgrave Macmillan.

Cartwright, D. and F. Haray (1956) Structural Balance: A Generalization of Heider's Theory. Psychological Review, 63: 277-93.

Confederación Nacional del Trabajo (CNT), Santiago de Compostela (2012) Estatutos de la Confederacion Nacional del Trabajo (Statutes of the National Confederation of Labor). Available online at http://cnt.es/sites/default/files/estatutos-cnt.pdf (accessed: 28 February 2012).

Connolly, H. and R. Darlington (2012) Radical Political Unionism in France and Britain: A Comparative Study of SUD-Rail and the RMT. European Journal of Industrial Relations, 18(3): 23550.

Connolly, H., L. Kretsos and C. Phelan (eds) (2014) Radical Unions in Europe and the Future of Collective Interest Representation. Brussels: Peter Lang. 
Denis, J-M. and R. Damesin (2005) SUD Trade Union: New Organisations trying to Conquer the French Trade Union Scene. Capital and Class, 29(2): 17-37.

Denis, J-M. (2012) The Case of SUD-Rail: The Limits of "Radical Political Unionism". European Journal of Industrial Relations, 18(3): 267-72.

Della Porta, D. (1998) Las motivaciones individuales en las organizaciones políticas clandestinas. In Los movimientos sociales: Transformaciones políticas y cambio cultural,. Madrid: Trotta.

Diani, M. (1998) Las redes de los movimientos: una perspectiva de análisis. In Los movimientos sociales: Transformaciones politicas y cambio cultural, edited by P. Ibarra and B. Tejerina. Madrid: Trotta.

Ebbinghaus, B., C. Göbel and S. Koos (2011) Social Capital, "Ghent" and Workplace Contexts Matter: Comparing Union Membership in Europe. European Journal of Industrial Relations, 17(2): 107-24.

Fernández Rodríguez, C.J., R. Ibáñez Rojo and M. Martínez Lucio (2014) Radical Trade Unionism in Spain: The Re-invention and Re-imagination of Autonomy and Democracy within and around the Union Movement during the Past Century. In Radical Unions in Europe and the Future of Collective Interest Representation, edited by H. Connolly, L. Kretsos and C. Phelan. Brussels: Peter Lang.

Florido, D., B. Roca and J.L. Molina (2013) Tightening the Screws: Workers Autonomy, Collective Action and Violence in the Shipyard of Puerto Real during the Second Shipbuilding Restructuring. Anthropological Quarterly, 85(3): 891-922.

Freeman, L.C. (2000) Visualizing Social Networks. Journal of Social Structure, 1(1). Available online at http://www.cmu.edu/joss/content/articles/volume1/Freeman.html.

Glassner, V. and T. Pusch (2013) Towards a Europeanization of Wage Bargaining? Evidence from the Metal Sector. European Journal of Industrial Relations, 19(2): 145-60.

Gollbach, J. and T. Schulten (2000) Cross-border Collective Bargaining Networks in Europe. European Journal of Industrial Relations, 6(2): 161-79.

Gómez Casas, J. (1984) Relanzamiento de la CNT 1975-1979. Madrid: CNT-AIT.

Gutiérrez Molina, J.L. (1993) La idea revolucionaria: el anarquismo organizado en Andalucía y Cádiz. durante los años treinta. Madrid: Madre Tierra/Las Siete Entidades.

Hurd, R.W., R. Milkman and L. Turner (2003) Reviving the American Labor Movement: Institutions and Mobilization. European Journal of Industrial Relations, 9(1): 99-117.

Ibáñez, T. (2007) Ilusión y desencanto en una misma entrega. Polémica, 60: marzo 2007. Available online at https://revistapolemica.wordpress.com/2012/12/27/ilusion-y-desencanto-en-unamisma-entrega.

Jódar, P., D. Garrell, S. Vidal and R. Alòs (2012) L'afiliació en CCOO Catalunya en els inicis del segle XXI. Barcelona: Comisiones Obreras.

Johnson, N.B. and P. Jarley (2005) Unions as Social Capital: The Impact of Trade Union Youth Programmes on Young Workers' Political and Community Engagement. Transfer: European Review of Labor and Research, 11(4): 605-16.

Juris, J. (2009) Networking Futures: The Movements against Corporate Globalization. North Carolina: Duke University Press.

Köhler, H-D. and J.P. Calleja Jiménez (2013) Trade Unions in Spain: Organisation, Environment, Challenges. Berlin: Friedrich Ebert Stiftung.

Letamendia, F. (2013) Acción colectiva, sindicalismo, regulación local y regional. In Sindicalismo en la 
empresa y el territorio: Una perspectiva anarcosindicalista e interdisciplinar, edited by Confederación Nacional del Trabajo. Zaragoza: Confederación Nacional del Trabajo.

McAdam, D., S. Tarrow and C. Tilly (2005) Dinámica de la contienda politica. Barcelona: Hacer. Molina, J.L. (2001) El análisis de redes sociales: Una introducción. Barcelona: Edicions Bellaterra.

Moreno, J. (1934) Who Shall Survive? New York: Beacon Press.

Nicholson, N., G. Ursell and P. Blyton (1981) The Dynamics of White Collar Unionism. London: Academic Press.

Offe, C. (1992) La sociedad del trabajo: Problemas estructurales y perspectivas de futuro. Madrid: Alianza.

Pérez de Guzmán, S. (2012) Negociación colectiva, acción sindical e intercambio político: Un planteamiento teórico apoyado en el análisis de las relaciones laborales en los astilleros de Cádiz. Papers: Revista de Sociología, 97(4): 773-94.

Putnam, R. D. (1999) Bowling Alone. New York: Touchstone.

Roca, B. and I. Díaz (2013) De la tierra a los supermercados: el SAT como ejemplo de particularismo militante y de renovación sindical. Anuario del Conflicto Social 2012: 855-91.

Schnabel, C. (2003) Determinants of Trade Unions Membership. In International Handbook of Trade Unions, edited by J.T. Addison and C. Schnabel, C. Cheltenham: Edward Elgar.

Tarrow, S. (1998) Power in Movement. Social Movements and Contentious Politics. Cambridge: Cambridge University Press.

Turnbull, P. (2010) From Social Conflict to Social Dialogue: Counter-mobilization on the European Waterfront. European Journal of Industrial Relations, 16(4): 333-49.

Urano, E.I. and P. Stewart (2009) Beyond Organised Labour in Japan: The Case Study of a Japanese Community Union Federation. In Community Unionism, edited by J. McBride and I. Greenwood. Basingstoke: Palgrave Macmillan.

Waddington, J. C. and Whitston (1997) Why do People join Unions in a Period of Membership Decline? British Journal of Industrial Relations, 35(4): 515-46.

\section{BIOGRAPHICAL NOTE}

Beltrán Roca is lecturer in Sociology at the Universidad de Cádiz in Spain. He is member of the research group GEISA and Flacso-España, and has been visiting researcher at CONICET (Argentina), Yale (USA), LSE (UK) and Aix-Marseille Université (France). His research interests are: trade unionism, migrations, third sector and collective action. His last book is Contrapoder sindical (Trade Union Counterpower) ((FAL, 2013). He has published in journals such as Anthropological Quarterly, Labour History, Voluntas or Non-profit Management \& Leadership. [Email: broca@us.es] 